\title{
The Right of Children to Free and Compulsory Education Act - 2009: As One of the Most Pioneering Academic Reforms in India
}

\author{
Ashok K. Saini ${ }^{1}$ \\ 1 Department of English Language \& Literature, Prince Sattam Bin Abdul Aziz University (Wadi-Al-Dawasir \\ Campus), Kingdom of Saudi Arabia \\ Correspondence: Dr. Ashok K. Saini, Ph.D., Department of English Language \& Literature, Prince Sattam Bin \\ Abdul Aziz University (Wadi-Al-Dawasir Campus), Kingdom of Saudi Arabia. Tel: 966-59-478-9658. \\ Received: March 30, 2016 \\ Accepted: April 18, $2016 \quad$ Online Published: June 17, 2016 \\ doi:10.5430/irhe.v1n2p58 \\ URL: http://dx.doi.org/10.5430/irhe.v1n2p58
}

\begin{abstract}
This research paper attempts to delineate and outline the critical study of The Right of Children To Free and Compulsory Education (RTE) Act - 2009 as one of the most pioneering academic reforms in India. India is one of the liberated countries with an affluent multicolored history, an amazingly multifaceted civilizing diversity in addition to a dedication to autonomous standards as well as welfare for all. The RTE Act besides this provides that no child shall be held back, expelled, or required to pass a board examination until the completion of elementary education. There is also a provision for special training of school drop-outs to bring them up to par with students of the same age. The Right to Education of persons with disabilities until 18 years of age has also been made a fundamental right. The Act provides for the establishment of the National Commission for Protection of Child Rights, and State Commissions for supervising proper implementation of the act, looking after complaints and protection of Child Rights. This RTE act will play a significant responsibility in achieving Universal Elementary Education in India. The RTE Act makes sure that any child can stipulate prerequisite of free education to him or her in his or her vicinity right up to the 8th class. It is furthermore asserted that the state will afford enforced basic schooling. The National Commission for Protection of Child Rights (NCPCR) has besides been designated the same agency to retain an ogle on provisions of the Act.
\end{abstract}

Keywords: cultural diversity, inclusive education, National Curriculum Framework (NCF), national policy, pooling resources, RTE Act -2009

\section{Introduction}

India is one of the open-minded countries with an affluent multicolored intellectual testimony, a miraculously multifaceted cultivating multiplicity in addition to a dedication to autonomous standards as well as welfare for all. The RTE - Act besides this provides that no child shall be held back, expelled, or required to pass a board examination until the completion of elementary education. In his speech, Dr. Manmohan Singh, former Prime Minister of India revealed that, "We are committed to ensure that all children, irrespective of gender and social categories, have access to education. An education that enables them to acquire the skills, knowledge, values and attitudes necessary to become responsible as well as active citizens of India." Beneath the umbrella of the RTE Act, 2009 , there are more than one crore kids who are not going to school at the present will be assisted to smoothen the growth of fundamental schooling. The RTE - Act is a scrupulous as well as prevalent piece of legislation which consists of necessities amalgamated to schools, teachers, curriculum, assessment, and right of entry in addition to explicit splitting up of responsibilities along with errands of dissimilar stakeholders. To pinnacle the great elements of the RTE-Act 2009 are:

1. Every child from 6 to 14 years of age has a right to free and compulsory education in a neighborhood school till completion of elementary education.

2. Private schools must take in a quarter of their class strength from 'weaker sections and disadvantaged groups' sponsored by the government.

3. All schools except private unaided schools are to be managed by School Management Committees with $75 \%$ parents and guardians as members. 
4. All schools except government schools are required to be recognized by meeting specified norms and standards within 3 years to avoid closure. (The New Indian Express: 2010).

The RTE-Act 2009 also provides that no child shall be held back, expelled, or required to pass a board examination until the completion of elementary education. There is also a provision for special training of school drop-outs to bring them up to par with students of the same age. The Right to Education of persons with disabilities until 18 years of age has also been made a fundamental right. The Act provides for the establishment of the National Commission for Protection of Child Rights, and State Commissions for supervising proper implementation of the act, looking after complaints and protection of Child Rights. Other provisions regarding improvement of school infrastructure, teacher-student ratio and faculty are also made in the Act. In this way, this Act makes education a fundamental right of every child between the ages group of 6 to 14 and specifies minimum norms in government schools. It has made a reservation of $25 \%$ of places in private schools for children from poor families, prohibits unrecognized schools from practice, and makes provisions for no donation or capitation fees and no interview of the child or parent for admission (Sripati, V.; Thiruvengadam, A. K. 2004: 2: 148).

As a significance milestone of education, this Act will dole out the same as a building block to make sure that each youngster has his or her right to acquire a value elementary education, in addition to that the State, in the company of assistance of ancestors as well as the public, fulfils this commitment. A small number of nations in this planet have such a nationalized prerequisite to make certain together free of charge moreover child-centered, child-friendly schooling to facilitate each and every one brood widen to their fullest prospective. There is no undeviating (educate fees) or circumlocutory charge (uniforms, textbooks, mid-day meals, transportation) to be abide by the teen or the parents to achieve basic schooling.

The administration will afford teaching free-of-cost in anticipation of a child's simple edification is fulfilled. The human race cannot disembark at its ambition to have each teen comprehend crucial school exclusive of India. Schools shall consist of School Management Committees (SMCs) consisting of neighboring authority bureaucrats, parents, custodians as well as instructors. The SMCs shall outline School Development Plans moreover scrutinize the exploitation of government fundings as well as the intact discipline and milieu. RTE Act 2009 in addition, authorizes the insertion of $50 \%$ women along with parents of broods from underprivileged groups in SMCs. Such society involvement will be essential to guarantying a child friendly "whole school" milieu in the course of detached toilet conveniences for girls as well as boys furthermore tolerable concentration to vigor, water, hygiene as well as cleanliness concerns.

By enforcement of the Right of Children to Free and Compulsory Education Act or Right to Education Act (RTE) Act on $1^{\text {st }}$ April 2010 India has become one of 135 countries to make education a fundamental right of every child. The Right of Children to Free and Compulsory Education Act or Right to Education Act (RTE) — passed by the Indian parliament on $4^{\text {th }}$ August 2009 describing the modalities of the provision of free and compulsory education for children between 6 and 14 under Article 21A of the Indian Constitution - is one of the most innovative endeavor of empowerment by Govt. of India.

This RTE act will play a significant responsibility in achieving Universal Elementary Education in India. The RTE Act makes sure that any child can stipulate prerequisite of free education to him or her in his or her vicinity right up to the 8th class. It is furthermore asserted that the state will afford enforced basic schooling. At the same time as it is accurate that a considerable number of students do not acquire education since there is no inexpensive school in the vicinity, especially in the clannish mountainous regions in addition to meagerly colonized wasteland districts, in a very large number of cases schooling is not the foremost precedence of the relatives. Importunate way of life is one of the apex concerns.

Kids functioning as rag-pickers, shoe-shine boys, household aid, in addition to customary otherwise treaty or piece-wage employees in numerous categories of industrial units in addition to on farmlands are an expected observable fact all over India, principally in the middling regions. The complete schools have to perform in accord by means of communications as well as teacher norms for an efficient erudition situation. Two trained teachers will be made available for every sixty students at the primary level. Educator are mandatory to be present at school repeatedly in addition to promptly, absolute core curriculum teaching, fine erudition facilities as well as clutch expected parent-teacher congregations.

The quantity of educator shall be foundation on the amount of learner relatively than by ranking. The state shall make sure tolerable maintenance to instructors leading to enhanced knowledge upshots of children. The public as well as civil society will have an imperative responsibility to cooperate in alliance in the midst of the SMCs to make certain 
school eminence through justness. The state will make available the guidelines skeleton as well as generate a facilitating milieu to guarantee RTE befall veracity for each child.

The RTE Act-2009 bequeath through a matured arena to accomplish the unreached, by way of explicit necessities for underprivileged factions, such as child employee, emigrant children, children with special requirements, or persons who have a "annoyance owing to societal, intellectual cost-effective, geological, linguistic, masculinity or such additional reasons." The Act further spotlights on the prominence of schooling as well as comprehension, which necessitates quick attempts along with extensive renovations:

- Creative and sustained initiatives are crucial to train more than one million new and untrained teachers within the next five years and to reinforce the skills of in-service teachers to ensure child-friendly education.

- Families and communities also have a large role to play to ensure child-friendly education for each and every one of the estimated 190 million girls and boys in India who should be in elementary school today.

- Disparities must be eliminated to assure quality with equity. Investing in preschool is a key strategy in meeting goals.

- Bringing eight million out-of-school children into classes at the age appropriate level with the support to stay in school and succeed poses a major challenge necessitating flexible, innovative approaches (BBC News).

In order to exert a pull on as well as preserve children from underprivileged family units to schools is not feasible in the course of obligation single-handedly, nor is it an issue of opening of schools in the vicinity. The children of these relatives stay behind unskillful since of the sheer catastrophe of their origin in such family units. They are required to not be permitted to undergo for no liability of theirs. They have the right to be skilled Education approach should scan the prospects of mingling vocation as well as school by plummeting the extent of school to presently half-a-day and/or by shifting the school timings. Meticulous troubles as well as evils have necessitated of extraordinary elucidations.

Schooling may be accessible when the kids are liberated from domestic conscientiousness or remunerated or honorary employment throughout night schools, mobile schools as well as the like. In the year 1966, the Kothari Commission has in addition confirmed that such coordination is indispensable to fabricate a collectively interrelated social order. Each and every child in specified environs, pinched from miscellaneous milieus, ought to be able to learn along with entertain simultaneously in a widespread unrestricted space. The Sarva Shiksha Abhiyan (SSA) instigated in the year 2001 to universalize value schooling, foresees escalating answerability of schools to the public through superior association of parish schooling working groups in addition to parent-teacher associations.

Subsequent to sovereignty, article - 45 under the recently outlined Constitution affirmed that the state shall venture to endow with, within an interlude of ten years from the inauguration of this Constitution, intended for complimentary in addition to essential education for all children in anticipation of the inclusive of age of fourteen years. As is manifested, yet subsequent to 60 years, worldwide elementary education vestiges a secluded delusion. Notwithstanding far above the ground enrolment rates of something like 95\% as per the Annual Status of Education Report (ASER 2009), 52.8\% of children studying in $5^{\text {th }}$ grade lack the reading skills expected at 2 nd grade.

Free and compulsory elementary education was made a fundamental right under Article 21 of the Constitution in December 2002, by the 86th Amendment. Most education experts agree that this amount will be insufficient. Since education falls under the concurrent list of the Constitution, financial negotiations were also undertaken between Central and State authorities to agree on sharing of expenses. This has been agreed at 35:65 between States and Centre; though state governments continue to argue that their share should be lower (Aarti Dhar, The Hindu).

Further more considerably, RTE Act 2009 endow with for the child's right to education that is liberated from trepidation, anxiety as well as apprehension. There are numerous necessities in the Act, including for instance, provisions eliminating physical retribution, incarceration as well as kicking out which necessitate to be fore-fronted to guarantee that we shift towards an organism that, as the National Policy on Education states, provides ' $a$ warm, welcoming and encouraging approach for children to learn' (NPE, 1986/92). The for the most part, imperative characteristic, on the other hand, is to guarantee that the teaching-learning progression is liberated from constant worry as well as apprehension (Sec. 29), in the company of evident inferences for curricular transformations. Testing as well as school grading organism must be assessed to stimulate children to make deeper as well as amplified their erudition. The RTE Act 2009 in addition lays down the responsibilities of instructor as well.

\section{Key Features of This Act}

There are following extensive key features of the RTE Act 2009: 
1. The right of children to free and compulsory education till completion of elementary education in a neighborhood school.

2. It clarifies that 'compulsory education' means obligation of the appropriate government to provide free elementary education and ensure compulsory admission, attendance and completion of elementary education to every child in the six to fourteen age group. 'Free' means that no child shall be liable to pay any kind of fee or charges or expenses which may prevent him or her from pursuing and completing elementary education.

3. It makes provisions for a non-admitted child to be admitted to an age appropriate class.

4. It specifies the duties and responsibilities of appropriate Governments, local authority and parents in providing free and compulsory education, and sharing of financial and other responsibilities between the Central and State Governments.

5. It lays down the norms and standards relating to, inter alia, Pupil Teacher Ratios, buildings and infrastructure, school working days, teacher working hours.

6. It provides for rational deployment of teachers by ensuring that the specified pupil teacher ratio is maintained for each school, rather than just as an average for the State or District or Block, thus ensuring that there is practically no urban-rural imbalance in teacher postings. It also prohibits deployment of teachers for non-educational work, other than decennial census, elections to local authority, state legislatures and parliament, and disaster relief.

7. It provides for appointment of appropriately trained teachers, i.e. teachers with the requisite training and academic qualifications.

8. For children in 6-14 age group it prohibits:

(i) Physical punishment and mental harassment,

(ii) Screening procedures for admission,

(iii) Capitation fees,

(iv) Private tuition by teachers,

(v) Running of schools without recognition,

9. It provides for the following penalties:

- For charging capitation fee: fine upto 10 times the capitation fee charged;

- For resorting to screening during admission: Rs 25,000 for first contravention; Rs 50,000 for each subsequent contravention; and

- For running a school without recognition: fine upto Rs one lakh, and in case of continuing contravention Rs 10,000 for each day during which the contravention continues.

10. It provides for development of curriculum in consonance with the values enshrined in the Constitution, and which would ensure the all round development of the child, building on the child's knowledge, potentiality and talent and making the child free of fear, trauma and anxiety through a system of child friendly and child centered learning.

11. It provides for protection and monitoring of the child's right to free and compulsory education and redressal of grievances by the National and State Commissions for Protection of Child Rights, which shall have the powers of a civil court (PTI, Feb. 13 $\left.{ }^{\text {th }}, 2010\right)$.

The National Commission for Protection of Child Rights (NCPCR) has besides been designated the same agency to retain an ogle on provisions of the Act. To guarantee that the RTE Act is implemented effectively and proficiently in letter in addition to fortitude, the NCPCR has taken the inventiveness to fabricate an accord amongst institutions, government departments, civil society as well as additional stakeholders. It has established a professional commission consisted of officials from a variety of government departments, persons of eminence as well as familiarity in the field of schooling, to focus on the roadmap for suitable accomplishment of the RTE.

\section{Conclusion}

Because it's integrated, RTE Act-2009 will be successfully able to make compulsory policy of inclusion effectively that requests to be put into practice in the entire schools along with the whole education system in India. It's further 
anticipated that as a result of the accomplishment of this act, contribution of each and every child will be secured in the entire spheres of their verve in as well as outside the school activities. Besides this act will be established as one of the most pioneering milestones in boosting the essential opportunities considered necessary to be specified to every child in addition to their explicit capabilities looked-for to be acknowledged, cherished as well as appreciated.

Consequently, educators will be desired to replicate to the highest degree on each and every facet of drill activities, i.e. performing more of a function in regulating along with disciplining as well as in cultivation ingenious learning moreover curiosity concerning education and culture. Sustaining controls and discipline in schools is by and large the privilege of trainers nevertheless this act will be booming in inculcating the value in addition to conventions of self-discipline which is considered as one of the most significant ingredients for the systematic pursuit of teaching and learning in addition to the improvement of the child's interests and potential. Accordingly, we will be competent enough to pursuit the performance, sovereignty, preference along with self-sufficiency equally for teacher as well as learner.

As the vast guidelines of this act present a visualization of what is enviable for our children, this will to a great extent authorize and empower to those authorities who are directly or indirectly involved with children as well as their education. This act emphasis more and more on an acceptance of concerns involving to children's over all learning, the temperament of comprehension in addition to the school as an establishment of teaching and learning. Hence, in various other ways as well, this act draws notice not only to the significance of the school philosophy and society, nevertheless to the classroom performance of teachers, learning sites exterior to the school, along with teaching and learning resources.

Subsequently, this act essentially emphasizes on the designing of large-scale curricular intercessions, enter academic activities such as the training of curriculum as well as textbooks, and assessment transformations and enhancement in the eminence of teaching and learning as a whole. Followed by this, edification is not simply one of the corporeal fixations that can be transported through a trainer however prolific and vigorous edification is constantly shaped, embedded in the substantial and intellectual loam of the child as well, and along with in addition nourished through interface with parents, teachers, fellow students as well as the neighborhood. Therefore, the roles and dignities of teachers will be paramounted, strengthened and underlined.

To conclude, UNICEF will in addition toil through allies to emphasize countrywide as well as state level administrative bodies of this RTE Act-2009. Alongside with guaranteeing accomplishment of the RTE Act which specifies listening carefully reorganization in government discipline as well as directives for private schools, we necessitate to expand our visualization so as to fashion a bio-network encouraging to impulsive concealed association. Accordingly, this is one of the most exceptional as well as astonishing alteration in the record of Indian schooling organism which make powerful the entire humanity right from house of Brickbuilder and Poly-bag Peeler to the Classroom. Instructor is the midpoint of excellent eminence of schooling and necessitates being compensated market-driven reimbursement. Nevertheless the government has disappeared excessively by necessitating sky-scraping tutor salaries per month. These wages are definitely out of contour, whilst weigh against with the marketplace wages of a tutor, for mainly schools in the majority of locations in the nation. Healthier machinery would have concerned school being acceptable to blueprint their individual tutor wage packages as well as having self-sufficiency to administer tutor.

\section{References}

Aarti Dhar (2010, $1^{\text {st }}$ April). Education is a fundamental right now. The Hindu. Retrieved from $\mathrm{http} / /$ beta.thehindu.com/news/national/article337111.ece?homepage $=$ true

Curriculum Framework for Teacher Education. (2006). NCTE. New Delhi.

Garrett, Henry E. (1989). Statistics in Psychology and Education. New Delhi: Paragon Publishers.

India launches children's right to education. $B B C$ News. $1^{\text {st }}$ April, 2010. Retrieved from http://news.bbc.co.uk/2/hi/8598167.stm

National Curriculum- A Framework. (2005). National Council of Education Research and Training, New Delhi.

National Policy on Education 1986 (with modification under taken in 1992) ministry of human resource development department of education, Government of India New Delhi-1992.

Parliament passes landmark Right to Education Bill. The Indian Express. 4 August 2009. Retrieved from http://www.indianexpress.com/news/parliament-passes-landmark-right-to-education-bill/497964/ 
PTI. (Feb 13, 2010). Right To Education Act to be implemented from April. New Delhi: The Times of India. Retrieved

from http://timesofindia.indiatimes.com/india/Right-To-Education-Act-to-be-implemented-from-April/articleshow/55 68857.cms

Seethalakshmi, S. (2006, July 14 ${ }^{\text {th }}$ ). Centre buries Right to Education Bill - India - The Times of India. The Times of India.

. Centre buries Right to Education Bill - India - The Times of India. The Times of India. Retrieved from http://timesofindia.indiatimes.com/articleshow/1748745.cms

Selva, G. (2009-03-22). Universal Education in India: A Century of Unfulfilled Dreams. PRAGOTI. Retrieved from http://www.pragoti.org/node/3262

Sharma, R. A. (1997). Advanced Education Technology, Meerut : Loyal Book Depot.

Sripati, V., \& Thiruvengadam, A. K. (2004). India: Constitutional amendment making the right to education a Fundamental Right. International Journal of Constitutional Law, 2, 148. http://dx.doi.org/10.1093/icon/2.1.148

The Indian $\quad$ Express. 4 August $2009 . \quad$ Retrieved from http://www.indianexpress.com/news/parliament-passes-landmark-right-to-education-bill/497964/ 